\title{
Brain and Hepatic Hsp70 Protein Levels in Heat- Acclimated Broiler Chickens During Heat Stress
}

Author(s)

Guerreiro EN ${ }^{1}$

Giachetto PF ${ }^{1}$

Givisiez PEN²

Ferro $\mathrm{JA}^{1}$

Ferro $\mathrm{MIT}^{1}$

Gabriel JE²

Furlan $\mathrm{RL}^{2}$

Macari $\mathrm{M}^{2}$

Departamento de Tecnologia - FCAV/Unesp

2 Departamento de Morfologia e Fisiologia Animal - FCAV/Unesp

\section{Mail Address}

Marcos Macari

Departamento de Morfologia da Fac. Ciências Agrárias e Veterinárias - FCAV/Unesp

Via de AcessoProf. Paulo Donato Castellane s/

14.884-900 - Jaboticabal, São Paulo, Brazil

E-mail: macari@fcav.unesp.br

\section{Keywords}

acclimation, broiler chickens, heat shock protein, heat stress.

\section{Acknowledgements}

The authors thank Fundação de Amparo à Pesquisa do Estado de São Paulo (FAPESP) for financial support.

\section{ABSTRACT}

In the present study we have investigated the effects of heat acclimation on brain and hepatic Hsp70 protein levels and body temperature of broiler chickens in response to gradual heat stress. Two groups of broilers were raised up to 47 days of age under distinct temperature conditions: thermoneutral (TN, according to bird age) or hot environmental $\left(\mathrm{HS}, 31-33^{\circ} \mathrm{C}\right)$. At 46 days of age, the birds reared at high ambient temperature were transferred to thermoneutrality conditions. After $18 \mathrm{~h}$, these birds and the birds reared at thermoneutral temperature were submitted to gradual heat stress in a climatic chamber so that environment temperature was increased from 28 to $40^{\circ} \mathrm{C}$ at a rate of $2^{\circ} \mathrm{C} / \mathrm{h}$. Colonic temperature was measured using a thermometer sensor probe at each two hours, and hepatic and brain tissues were collected immediately after slaughter in order to assess Hsp70 protein level by Western blotting analysis. The colonic temperatures of birds reared at high temperature increased steeply during the first $2 \mathrm{~h}$ of heat stress $\left(1.06^{\circ} \mathrm{C} / \mathrm{h}\right)$ and more slowly thereafter $\left(0.59^{\circ} \mathrm{C} / \mathrm{h}\right)$. Broilers reared at thermoneutral temperature showed a small increase in the first $4 \mathrm{~h}$ of heat stress $\left(0.18^{\circ} \mathrm{C} / \mathrm{h}\right)$ and then colonic temperature increased sharply $\left(0.72^{\circ} \mathrm{C} / \mathrm{h}\right)$. Nevertheless, both groups presented similar final colonic temperature by the end of the stress period. Hsp70 levels (ng Hsp70 $\mu$ g total protein ${ }^{-1}$ ) did not change in the liver or brain of the birds reared at high temperature. On the other hand, both liver and brain Hsp70 levels increased significantly during heat stress in the animals reared at thermoneutrality, with a higher expression of this peptide in brain tissue.

\section{INTRODUCTION}

Living organisms respond to changes in environmental temperature by activation of physiological mechanisms involved in heat loss or production. Several cellular events are triggered when cells and organisms are exposed to stress injury. Nevertheless, the activation of these responses seems to be transient since they are blocked after a return to the non-stressing physiological state. If the animal or the cell is not able to react or adapt to these environmental changes, homeostasis may be compromised and even death may occur.

In the poultry industry, a high mortality rate and impaired performance of broiler chickens have been recorded with alterations in ambient temperature (Arjona et al., 1988). Heat stress has generated significant economic losses to the Brazilian poultry industry. During summer and also during the "veranico" (hot days and cold nights that occur during Spring and Autumn), heat stress is responsible for the morbidity and mortality of one million broilers per month (Macari et al., 2002). Adult birds are the most affected by high ambient temperatures and emphasis 
Guerreiro EN, Giachetto PF, Givisiez PEN, Ferro JA, Ferro MIT, Gabriel JE, Furlan RL, Macari M
Brain and Hepatic Hsp70 Protein Levels in Heat-Acclimated Broiler Chickens During Heat Stress has been placed on procedures such as feed restriction, changes in diet composition and environmental management (fogging and fans) in order to minimize temperature negative effects.

The physiological and molecular mechanisms involved in the stress response have been extensively investigated in a wide variety of species. It has been well characterized that this emergency response is marked by a drastic reduction in cellular protein synthesis, except for a set of proteins named heat shock proteins (Hsps), whose synthesis is perceptibly increased under stressing conditions (Craig, 1985). These proteins are highly conserved among species and some evidences suggest that their function is to protect stressed cells and organisms, preventing or reversing disorders caused by stress. Other stressing agents besides changes in environment temperature can activate specific heat shock genes, with a consequent increase in synthesis and levels of intracellular Hsps (Hahn et al., 1991).

Studies have demonstrated that previous exposure of animals or cultured cells to mild temperatures is enough to induce thermotolerance in response to a subsequent lethal stress (Lindquist \& Craig, 1988). In spite of the many lines of evidence showing that the expression of $70 \mathrm{kDa}$ heat shock protein (Hsp70) is time- and temperature-dependent in broiler chickens (Gabriel et al, 1996), the role of these proteins in the thermotolerance phenomenon in poultry has not been fully elucidated. Based on this evidence, the purpose of the present study was to investigate the effects of heat stress on brain and hepatic Hsp70 protein levels and body temperature in heat-acclimated broiler chickens.

\section{MATERIALS AND METHODS}

\section{Bird management and temperature conditions}

A total of 300 one-day-old female broiler chickens of a commercial strain (Cobb) were reared at a density of $10 \mathrm{birds} / \mathrm{m}^{2}$ in pens covered with $10 \mathrm{~cm}$ of wood shavings as litter material. The birds were divided in two groups of 150 birds and housed in two distinct environmentally controlled rooms, where ambient temperature was controlled to thermoneutrality according to bird age (thermoneutral temperature, TN) or to high ambient temperature (heat acclimated, HS) (Table 1). At 47 days of age, birds of both treatments, TN and HS, were submitted to gradual heat stress. Initially, birds raised at high ambient temperature were kept for $18 \mathrm{~h}$ at thermoneutral ambient condition (21$25^{\circ} \mathrm{C}$ ) before exposure to gradual heat stress. During the gradual heat stress, birds were placed in individual cages $(0.60 \times 0.50 \times 0.45 \mathrm{~m})$ with no food or water available inside an environmentally controlled room. Initial room temperature was $28^{\circ} \mathrm{C}$ and it was raised $2^{\circ} \mathrm{C}$ per hour up to $42^{\circ} \mathrm{C}$. Colonic temperature of 16 birds was measured at one hour intervals using a telethermometer (Yellow Spring Instruments, model 46 TUC) and a probe inserted $5 \mathrm{~cm}$ in the colon (probe YSI n० 702). Two birds per treatment at each temperature $\left(28,30,32,34,36,38,40\right.$, and $\left.42^{\circ} \mathrm{C}\right)$ were randomly chosen and sacrificed by cervical dislocation. Brain and hepatic tissue samples were immediately collected and frozen in liquid nitrogen for later analysis. The diets used in the experiment were based on corn and soybean meal and broilers were fed a diet containing 3,200 kcal ME/kg and $23 \%$ of crude protein content in the starter phase (1 to 21 days of age) and $20 \%$ of crude protein in the grower phase (22 to 47 days of age).

\begin{tabular}{|c|c|c|}
\hline \multicolumn{3}{|c|}{ Environmental temperature $\left({ }^{\circ} \mathrm{C}\right)$} \\
\hline Age (d) & Thermoneutral (TN) & High Temperature (HS) \\
\hline $1-7$ & $31-33$ & $31-33$ \\
\hline $8-14$ & $28-31$ & $31-33$ \\
\hline $15-21$ & $25-28$ & $31-33$ \\
\hline $22-45$ & $21-25$ & $31-33$ \\
\hline
\end{tabular}

\section{Determination of Hsp70 protein levels by Western blotting analysis}

Brain and liver samples were homogenized three times (1 min each time) in $10 \mathrm{~mL}$ of lysis buffer $(20 \mathrm{mM}$ Tris- $\mathrm{HCl}, \mathrm{pH} 7.5,9 \mathrm{~g} / \mathrm{L} \mathrm{NaCl}, 2 \mathrm{mM}$ b-mercaptoethanol) at $20,000 \mathrm{rpm}$ with ice-bath intervals of $30 \mathrm{~s}$. Total lysate was centrifuged at $3,100 \mathrm{~g}$ for $30 \mathrm{~min}$ at $4^{\circ} \mathrm{C}$ and the supernatants were manually homogenized 10 times with a Potter-Elvehjem homogenizer. Aliquots were separated for total protein determination and electrophoresis. Three hundred $\mu \mathrm{L}$ of $2 \mathrm{x}$ sample buffer (125 mM Tris- $\mathrm{HCl}, \mathrm{pH}$ 6.8, $200 \mu \mathrm{L} / \mathrm{L}$ glycerol, $40 \mathrm{~g} / \mathrm{L}$ SDS, $0.02 \mathrm{~g} / \mathrm{L}$ bromophenol blue) and $40 \mu \mathrm{L} \mathrm{b-}$ mercaptoethanol were added to the liver electrophoresis samples, whereas the brain samples were prepared by the addition of $300 \mu \mathrm{L}$ of $4 \mathrm{x}$ sample buffer $(250 \mathrm{mM}$ Tris-HCl, pH 6.8, $400 \mu \mathrm{L} \mathrm{L} / \mathrm{L}$ glycerol, $80 \mathrm{~g} / \mathrm{L}$ SDS, $0.02 \mathrm{~g} / \mathrm{L}$ bromophenol blue) and $40 \mu \mathrm{L} \mathrm{b}$ mercaptoethanol. The protein concentration of 
Guerreiro EN, Giachetto PF, Givisiez PEN, Ferro JA, Ferro MIT, Gabriel JE, Furlan RL, Macari M
Brain and Hepatic Hsp70 Protein Levels in Heat-Acclimated Broiler Chickens During Heat Stress supernatant aliquots was determined as described by Hartree (1972) using standard curves obtained from triplicate samples of bovine serum albumin solution (Sigma) ranging from 0 , to $20,40,60,80$ and $100 \mu \mathrm{g}$. Ten $\mu \mathrm{g}$ of total protein for brain and $30 \mu \mathrm{g}$ for liver were loaded and separated on $9 \%$ polyacrylamide gels under denaturing conditions (Sambrook et al., 1989). A pooled sample of one-day-old chickens was loaded onto all gels as a reference standard in order to estimate Hsp70 levels. The pool was a mixture of equal quantities of total protein of the supernatant obtained from different birds and was specific for each tissue (liver and brain).

Proteins were transferred from the SDSpolyacrylamide gels to polyvinylidene difluoride (PVDF Hybond $\mathrm{P}$, Amersham) membranes as described by Towbin et al. (1979). Membranes were then incubated for one hour at room temperature with monoclonal anti-Hsp70 antibody (H-5157, Sigma) in $10 \mathrm{~mL}$ of cold TBST-milk buffer (10 mM Tris-HCl pH 8.0; $150 \mathrm{mM}$ $\mathrm{NaCl}, 50 \mathrm{~g} / \mathrm{L}$ non-fat skimmed milk; 0.02 \% Tween20) at a final dilution of 1:1,000. After four washings of $5 \mathrm{~min}$ in $10 \mathrm{~mL}$ of TBST buffer (without non-fat skimmed milk, membranes were incubated with $2 \mu \mathrm{L}$ anti-mouse antibody conjugated to alkaline phosphatase (A-5153, Sigma) and diluted in $10 \mathrm{~mL}$ of cold TBS-milk solution (1:5,000 dilution) for one hour at room temperature under constant shaking. The membranes were then rinsed with cold TBST buffer under the same conditions as described above. The color reaction was developed in the presence of specific chromogenic substrates until the visualization of the Hsp70 band (approximately $2 \mathrm{~min}$ ), when the reaction was blocked by the addition of trichloroacetic acid (30 $\mathrm{mL} / \mathrm{L}$ ). The color signal of the bands corresponding to Hsp70 was determined by densitometry (Shimadzu CS9301) using the reflection mode and zigzag scanning at $525 \mathrm{~nm}$.

Hsp70 levels were quantified by direct comparison with standard curves constructed from known amount of purified Hsp70 (H-9776, Sigma) (Givisiez et al., 1999). Aliquots containing 50, 100, 200, 400, 600 and $800 \mathrm{ng}$ of purified Hsp70 as well as aliquots of reference standard samples were loaded onto the electrophoresis gel. Polyacrylamide gel electrophoresis and Western Blot analysis were performed as previously described. The band signals corresponding to the increasing concentrations of Hsp70 protein were evaluated by densitometry and expressed as the ratio between the density of each band and the mean density of the reference standard, which was analysed in triplicate.
Hsp70 concentrations were then plotted against the density ratio of each concentration and a standard curve was constructed. The Hsp70 levels in brain and liver samples from the different treatments were evaluated by a similar procedure. Density ratios between samples and the specific reference standard were calculated, then the concentrations were determined according to the standard curve and expressed as ng Hsp70/ug total protein.

\section{Statistical Analysis}

Data were analyzed in a completely randomized design using the General Linear Model (GLM) procedure of SAS ${ }^{\circledR}$ (SAS Institute, 2000). Differences between means were determined by Tukey's test at the $5 \%$ level of probability $(p<0.05)$.

\section{RESULTS}

The influence of environmental rearing temperature on body weight, feed intake and feed conversion of broiler chickens is presented in Table 2. Birds that were reared at high temperature had lower body weight and worse feed conversion than birds reared at thermoneutral temperature $(p<0.05)$. Although ambient temperature did not affect feed intake until 21 days of age, birds kept at high temperature showed lower feed intake between 21 to 42 days of age compared to the birds reared under thermoneutral conditions.

\footnotetext{
Table $\mathbf{2}$ - Means of body weight gain, feed intake and feed conversion of broiler reared in high temperature (HS) or thermoneutrality (TN).
}

\begin{tabular}{|c|c|c|c|}
\hline Treatment & 1-21 days & 21-42 days & 1-42 days \\
\hline \multicolumn{4}{|c|}{ Body weight gain (g) } \\
\hline TN & $461 a$ & $1,422 a$ & $1,883 a$ \\
\hline HS & $395 b$ & $948 b$ & $1,343 b$ \\
\hline \multicolumn{4}{|c|}{ Feed intake (g) } \\
\hline TN & $607 a$ & $2,777 a$ & $3,384 a$ \\
\hline HS & $608 a$ & $2,246 b$ & $2,855 b$ \\
\hline \multicolumn{4}{|c|}{ Feed conversion } \\
\hline TN & $1.31 \mathrm{~b}$ & $1.95 b$ & $1.80 \mathrm{~b}$ \\
\hline HS & $1.54 a$ & $2.40 \mathrm{a}$ & $2.13 a$ \\
\hline
\end{tabular}

Variation in colonic temperatures $\left(T_{c}\right)$ of broiler chickens during gradual heat stress was determined every hour, and is shown in Figure 1. Heat-acclimated birds showed a steep increase during the first $2 \mathrm{~h}$ of 
Guerreiro EN, Giachetto PF, Givisiez PEN, Ferro JA, Ferro MIT, Gabriel JE, Furlan RL, Macari M
Brain and Hepatic Hsp70 Protein Levels in Heat-Acclimated Broiler Chickens During Heat Stress stress $\left(1.06^{\circ} \mathrm{C} / \mathrm{h}\right)$, followed by a slower increase thereafter $\left(0.59^{\circ} \mathrm{C} / \mathrm{h}\right)$, and reached $44.85^{\circ} \mathrm{C}$ at the end of the heat stress episode. On the other hand, TN birds showed a small increase in $T_{c}$ during the first $4 \mathrm{~h}$ of stress $\left(0.18^{\circ} \mathrm{C} / \mathrm{h}\right)$, followed by a sharp increase at a rate of $0.72^{\circ} \mathrm{C} / \mathrm{h}$, reaching $44.12^{\circ} \mathrm{C}$ at the end of the heat stress episode. It is worth noting that both groups reached the same final colonic temperature by the end of the stress period (Figure 1).

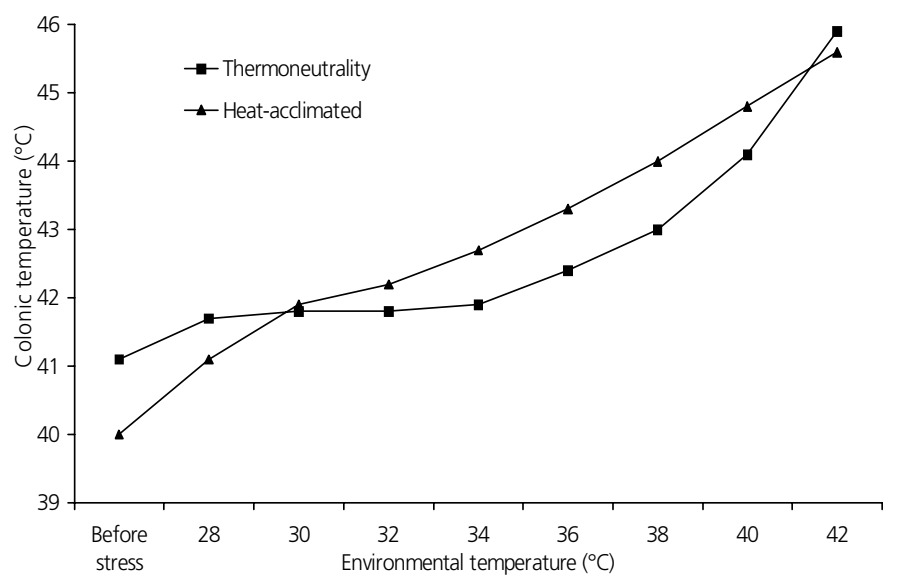

Figure 1 - Colonic temperature $\left({ }^{\circ} \mathrm{C}\right)$ of heat-acclimated broiler and control broilers during the gradual heat stress.

Brain and hepatic Hsp70 levels of TN and HS birds are shown in Table 3. Hsp70 protein levels in the brain of heat acclimated broilers remained unaltered during gradual heat exposure $(p>0.05)$. Nevertheless, brain Hsp70 levels increased significantly in TN birds during the heat stress episode $(p<0.05)$, with higher levels of this protein being observed when ambient temperature reached values equal to or higher than $36^{\circ} \mathrm{C}$. Hepatic Hsp70 levels were similar between the two treatments up to $34^{\circ} \mathrm{C}$, whereas the lower content of this peptide was observed in heat-acclimated birds (HS) between 36 and $42^{\circ} \mathrm{C}$. Increases in Hsp70 protein levels were more marked in brain than in liver samples.

\section{DISCUSSION}

Our findings showed that heat acclimation is able to affect the thermoregulatory events of broiler chickens, resulting in enhanced colonic temperature. No difference was detected in brain or hepatic Hsp70 protein levels in heat-acclimated birds during gradual heat stress. The higher colonic temperature of broilers acclimated to a hot environment has been proposed to be a defense mechanism, since it reduces the thermal load and the use of body water to dissipate the heat by evaporative mechanisms. Several studies have reported that broilers exposed to hot ambient temperatures at the end of the growing phase presented higher rectal temperature than control birds (Reece et al., 1972; May et al., 1987; Wiernusz \& Teeter, 1996). Nevertheless, 5-day-old chicks exposed to heat stress for $24 \mathrm{~h}$ showed similar (Arjona et al., 1990) or lower (Yahav \& Hurwitz, 1996) rectal temperature at 43 days of age when compared to birds not submitted to neonatal heat stress. These findings suggest that exposure to heat stress during rearing may determine changes in the thermotolerance of birds at the end of the growing phase, although only a few convincing data related to this adaptive mechanism are available in the literature. Our results suggest that broiler chickens are able to develop mechanisms associated with heat tolerance since the pattern of increase in colonic temperature observed during gradual heat stress seems to be involved in their ability to tolerate high ambient temperature. The rate of increase in colonic temperature during the heat stress episode in the heat-acclimated birds might be associated with the process of reducing water loss in order to prevent dehydration. Additionally, SchmidtNielsen (1979) showed that enhancements in colonic temperature allow the birds to tolerate high environmental temperatures through conductive and radiant heat loss mechanisms. Yahav et al. (1997) reported that the hyperthermia observed in heatacclimated broilers is a result of the lack of a cardiovascular system response, and suggested that hemodynamic changes are necessary to confer resistance to heat stress. Thus, the identification of additional physiologic mechanisms involved in cardiovascular hemodynamic changes and in the acquisition of thermotolerance in heat-acclimated broiler chickens requires further study.

Brain and hepatic Hsp70 protein concentrations in heat-acclimated birds (HS) and in birds reared at thermoneutrality (TN) showed that the expression of this protein is tissue-dependent (Table 3). The brain Hsp70 levels were 3 to 4 times higher than in the hepatic tissue of heat- stressed birds reared at thermoneutrality. No differences were observed in the liver or brain Hsp70 levels of heat-acclimated broilers during the episode of gradual heat increase ( $p>0.05$ ). Increases in brain Hsp70 levels in non-acclimated birds were more marked after ambient temperature had 
Guerreiro EN, Giachetto PF, Givisiez PEN, Ferro JA, Ferro MIT, Gabriel JE, Furlan RL, Macari M
Brain and Hepatic Hsp70 Protein Levels in Heat-Acclimated Broiler Chickens During Heat Stress

\begin{tabular}{|c|c|c|c|c|c|c|c|c|}
\hline & \multicolumn{8}{|c|}{ Environmental Temperature $\left({ }^{\circ} \mathrm{C}\right)$} \\
\hline & 28 & 30 & 32 & 34 & 36 & 38 & 40 & 42 \\
\hline \multicolumn{9}{|c|}{ Brain } \\
\hline Heat acclimated & $28.33 \mathrm{Aa}$ & $27.12 \mathrm{Aa}$ & $28.86 \mathrm{Aa}$ & $22.69 \mathrm{Aa}$ & 23.09Ab & $20.95 \mathrm{Ab}$ & 25.91Ab & $24.57 \mathrm{Aa}$ \\
\hline Thermoneutrality & $23.23 \mathrm{Ba}$ & $24.44 \mathrm{Ba}$ & $20.54 \mathrm{Bb}$ & $26.85 \mathrm{Ba}$ & 39.06Aa & 41.48Aa & 39.46Aa & $31.41 \mathrm{Ba}$ \\
\hline \multicolumn{9}{|c|}{ Liver } \\
\hline Heat acclimated & 6.63Aa & 5.03Aa & 5.31Aa & 4.83Ba & $6.18 \mathrm{Ab}$ & 5.00Ab & 5.87Aa & $5.80 \mathrm{Ab}$ \\
\hline Thermoneutrality & 5.62Aa & 5.10Ba & $4.48 \mathrm{Ba}$ & $5.52 \mathrm{Aa}$ & 7.12Aa & 7.74Aa & 7.64Aa & 7.67Aa \\
\hline
\end{tabular}

reached $36^{\circ} \mathrm{C}$, when their colonic temperature was more than $43^{\circ} \mathrm{C}$. Flanagan et al. (1995) suggested that the different accumulative profiles of $\mathrm{Hsp} 70$ in tissues may be due to the different temperatures to which tissues are submitted. As reported by Schmidt-Nielsen (1995), some species present mechanisms that do not allow the brain to change its temperature, which is kept 2 or $3^{\circ} \mathrm{C}$ lower than rectal temperature. Nonetheless, when the physiological limit of thermoregulation is exceeded during a stressing condition, little changes in brain temperature would be insufficient to induce an accumulation of Hsp70 in this tissue. We could only speculate that in heatacclimated broilers the activation of mechanisms associated with thermotolerance is marked by increases in colonic temperature during exposure to heat stress, and that no differences are observed at the molecular level in brain and hepatic Hsp70 protein levels due to the small alteration in internal temperature of these tissues during heat stress. The effect of exposure of chicks to heat during the neonatal phase on thermotolerance in adult birds was previously investigated (Yahav et al., 1997). Birds were thermotolerant to heat stress at 42 days of age, but the concentrations of Hsp70 in the heart and lungs of these animals were lower than in the control birds, suggesting that this protein did not play an important role in the mechanism involved in thermotolerance. It has been well documented that the increased synthesis of Hsp70 in response to heat shock is not necessarily sufficient to induce thermotolerance and even may not be required during mouse embryo heat exposure (Hansen, 1999). Our findings reinforce the notion that Hsp70 alone is probably insufficient for induced thermotolerance in birds, and further studies are needed to investigate the participation of other molecules during heat acclimation of broiler chickens.

Alternatively, the decreased Hsp70 levels observed under the conditions of the present study may not be associated with changes in the stability of this peptide, since it has been well characterized that heat shock proteins and their transcripts present high stability compared to other genes when organisms are exposed to the action of stressing agents (Lindquist \& Craig, 1988). Nevertheless, the existence of a relationship between the cellular and neuroendocrine stress responses in tissues of intact animals has been proposed based on the observation that hypophysectomized rats did not present Hsp gene expression in response to restraint stress, and that administration of stress-related hormones such as ACTH to these rats induced Hsp70 synthesis in the adrenals (Blake et al., 1990). Based on this evidence, the cited authors suggested that higher levels of circulating cortisol could inhibit Hsp70 synthesis by binding to cortisol receptors in the cytosol. Glucocorticoid receptor complexes contain Hsp70, which may be released upon binding with cortisol and, as a result, increased levels of free Hsp70 may inhibit specific transcription factors and subsequent Hsp70 expression (Morimoto et al., 1996). Thus, elucidation of the various signal pathways that regulate Hsp production and degradation will contribute significantly in this regard.

\section{CONCLUSION}

The results of the present study show that heat acclimation affects the response of broilers during a heat stress episode. However, despite the higher hepatic and brain Hsp70 contents, the involvement of this protein in the development of thermotolerance is not fully guaranteed.

\section{REFERENCES}

Arjona AA, Denbow DM, Weaver Jr WD. Effect of heat stress early in life on mortality of broilers exposed to high environmental temperatures just prior to marketing. Poultry Science 1988; 67:226231 
Guerreiro EN, Giachetto PF, Givisiez PEN, Ferro JA, Ferro MIT, Gabriel JE, Furlan RL, Macari M
Brain and Hepatic Hsp70 Protein Levels in Heat-Acclimated Broiler Chickens During Heat Stress
Arjona AA, Denbow DM, Weaver Jr WD. Neonatally induced thermotolerance: physiological responses. Comparative Biochemistry Physiology 1990; A95:393-399.

Blake MJ, Nowak, TS, Holbrook, NJ. In vivo hyperthermia induces expression of Hsp70 mRNA in brain regions controlling the neuroendocrine response to stress. Molecular Brain Research 1990; 8:89-92

Craig E. The heat shock response. Critical Review of Biochemistry 1985; 18:239-280.

Flanagan SW, Ryan AJ, Gisolfi CV, Moseley PL. Tissue-specific HSP70 response in animals undergoing heat stress. American Journal of Physiology (Regulatory Integrative Comparative Physiology 1995; 268:R28-R32

Gabriel JE, Ferro JA, Stefani RMP, Ferro MIT, Gomes SL, Macari M. Effect of acute heat stress on heat shock protein 70 messenger RNA and on heat shock protein expression in the liver of broilers. British Poultry Science 1996; 37:443-449.

Givisiez PE, Ferro JA, Ferro MI, Kronka SN, Decuypere E, Macari M. Hepatic levels of heat shock protein $70 \mathrm{kDa}$ (Hsp70) in broilers submitted to different thermal treatments. British Poultry Science 1999; 40:292-296.

Hahn GM, Shiu EC, Auger EA. Mammalian stress proteins Hsp70 and Hsp28 co-induced by nicotine and either ethanol or heat. Molecular Cell Biology 1991; 11:6034-6040.

Hansen PJ. Possible roles for heat shock protein 70 and glutathione in protection of the mammalian preimplantation embryo from heat shock. Annual Review of Biomedical Science 1999; 1:5-29.

Hartree EF. Determination of protein: A modification of the Lowry method that gives a linear photometric response. Analytical Biochemistry 1972; 48:422-427.

Lindquist S, Craig EA. The heat shock proteins. Annual Review of Genetics 1988; 22:631-677.

Macari M, Furlan RL, Gonzales E. Fisiologia aviária aplicada a frangos de corte. Jaboticabal (SP): FUNEP; 2002. 375 p.

May JD, Deaton JW, Branton SL. Body temperature of acclimated broilers during exposure to high temperature. Poultry Science 1987; 66:378-380.

Morimoto RI, Kroeger PE, Cotto JJ. The transcriptional regulation of the heat shock genes: A plethora of heat shock factors and regulatory conditions. In: Feige U, Morimoto RI, Yahara I, Polla B editors. Stress-inducible cellular responses. Basel: Birkhauser; 1996. p.139-164.

Reece FN, Deaton JW Kubena LF. Effects of high temperature and humidity on heat prostration of broilers chicken. Poultry Science 1972; 51: 2021-2025.

SAS Institute. User's guide: statistics. Cary, NC; 2000.
Sambrook J, Fritsch E F, Maniatis T. Molecular cloning: a laboratory manual. $2^{\text {nd }}$ ed. Cold Spring Harbor: Cold Spring Harbor Laboratory Press, 1989.

Schmidt-Nielsen K. Desert birds. In: Schmidt-Nielsen K. editor. Desert animals: physiological problems of heat and water. New York: Dover Publ. Inc.; 1979. p.204-224.

Schmidt-Nielsen K. Animal physiology: adaptation and environment. New York: Cambridge University Press; 1995. p. 241-293.

Towbin H, Staehelin T, Gordon J. Electrophoretic transfer of proteins from polyacrylamide gels to nitrocellulose sheets: procedure and some applications. Proceedings of National Academy of Sciences USA 1979, 76:4350-4354.

Wiernusz CJ, Teeter RG. Acclimation effects on fed and fasted broiler thermobalance during thermoneutral and high ambient temperature exposure. British Poultry Science 1996; 37:677-687.

Yahav S, Hurwitz S. Induction of thermotolerance in male broiler chickens by temperature conditioning at an early age. Poultry Science 1996; 75:402-406.

Yahav S, Shamay A, Horev G, Bar-llan D, Genina O, Friedman-Einat $M$. Effect of acquisition of improved thermotolerance on the induction of heat shock proteins in broiler chickens. Poultry Science 1997; 76:1428-1434. 